\title{
Aspek-aspek Hukum Alih Teknologi dalam Meningkatkan Daya Saing Produksi Teknologi Pertambangan di Indonesia
}

\author{
Sri Wartini
}

\begin{abstract}
These writings try to discuss the international and national law aspects in developing the competitive power on mining technology production in Indonesia including the gaps appear between the law aspect of technological transfer nationally and and internationally as well. Besides that, it discusses about the kinds of technology look like which it could develop the competitive power of mining technological product in Indonesia.
\end{abstract}

\section{Pendahuluan}

Industrialisasi merupakan tujuan utama bagi negara berkembang untuk dapat mencapai tingkat kesejahteraan yang lebih baik. Kemajuan ilmu pengetahuan dan teknologi sangat berperan dalam pertumbuhan industri. Pengembangan dasar teknologi di negara berkembang termasuk Indonesia tergantung pada berbagai kapasitas teknologi dan kemampuan memperoleh teknologi dari negara maju untuk melengkapi usaha-usaha dan riset nasional serta pertumbuhan teknologi yang diciptakan di dalam negeri. Dalam waktu yang bersamaan, sebagai negara penerima teknologi tentu akan menerima dampak yang tidak dapat dihindari baik dalam pola konsumsi, lingkungan maupun nilai-nilai budaya. ${ }^{1}$

Proses pengalihan teknologi melibatkan kegiatan-kegiatan yang sering berhubungan dengan identifikasi kebutuhan teknologi

Untuk informasi lebih lanjut tentang dimensi.budaya teknologi, lihat A.A. Mazrui. " Exit from the World System: Dilemmas of Cultural and Economic Disengagement. "Dalam A. Gauhar. 1983.Third World Startegy Economic and Politic Cohesion in the South. New York: Praegar. HIm. 144. 
sesuai dengan kebutuhan pembangunan sosial ekonomi negara yảng bersangkutań. Selain itu faktor lain yang tidak kalah penting ialah identifikasi hambatan dalam alih teknologi ke negara berkembang dan kemudahan-kemudahan yang dapat diberikan oleh negara maju pemilik teknologi,yaitu dalam hal penentuan persyaratan yang adil dan rasional baik dalam materi teknisnya maupun dalam proses pengalihannya kepada negara berkembang, sehingga dapat membantu negara tersebut dalam pengembangan teknologi yang disesuaikan dengan struktur produksi negara yang bersangkutan.

Pasal 33 UUD 1945 yang menyatakan bahwa "bumi, air, dan kekayaan yang terkandung di dalamnya dikuasai oleh negara dan dipergunakan untuk sebesar-besarnya kemakmuran rakyat". Berdasarkan ketentuan tersebut, negara memiliki kekuasaan untuk mengatur pemanfaatan dan peruntukan kekayaan, dalam hal ini meliputi pula hasil tambang. Hasil tambang di Indonesia belumlah memperoleh perhatian yang optimal dari pemerintah, sehingga deviša yang dihasilkan dari komoditi ini belumlah seimbang dengan kekayaan tambang yang dimiliki oleh Indonesia: Untuk lebih meningkatkan daya saing produksi teknologi pertambangan di Indonesia sangatlah diperlukan adanya alih teknologi dan perangkat hukum yang mengaturnya.

Landasan filsafat yang mendorong perlu adanya alih teknologi dari-negara maju kepada negara berkembang dapat dilihat pada ketentuan dalam "Declaration on the Progressive Development of Principles of Public International Law Relation to A New International Economic Order". Dalam Deklarasi tersebut, antara lain menyebutkan bahwa setiap negara memiliki hak untuk mendapatkan manfaat/ keuntungan dari ilmu pengetahuan dan teknologi khususnya dari negara-negara maju kepada negara-negara berkembang.

Perjanjian-perjanjian mengenai alih teknologi, pada dasarnya merupakan hubungan kontraktual semata antara pembeli dan penjual. Perjanjian tersebut melibatkan pihak lokal sebagai pembeli dan penerima teknologi. dan keahlian dari perusahaan asing. Indonesia, hingga saat ini belum memiliki peraturan perundang-undangan tersendiri mengenai alih teknologi. Oleh karena itu, perjanjian-perjanjian alịh teknologi.tunduk kepada hukum perjanjian yang berlaku pada umumnya yaitu KÜHPerdata, sedangkan ketentuan-ketentuan mengenai alih teknologi secara tidak langsung dapat ditemukan dalam undang-undang merek, undang-undang hak cipta, Dạn undang-undang paten.

Perjanjian alih teknologi pertambangan yang lazim dilakukan di Indonesia adalah perjanjian lisensi, melalui perjanjian lisensi ini dimungkinkan untuk mengalihkan paten dan bantuan teknik serta know how. Perundangundangan alih teknologi bagi negara yang sedang berkembang seperti Indonesia, memiliki arti penting khususnya dalam membantu posisi swasta nasional dalam bernegosiasi dengan negara industri. Posisi monopoli pemilik teknologi umumnya dilindungi oleh ketentuan perundangundangan dinegaranya. Apabila suatu negara belum dilindungi oleh ketentuan-ketentuan perundang-undangan alifh teknologi; seperti Indonesia akan terjadi ketidak seimbangan di dalam melakukan perjanjian. 


\section{Pengertian Teknologi}

Teknologi telah menyebabkan banyak perubahan dalam peradapan manusia, dan pada era modern sekarang ini telah menjadi faktor penentu keberhasilan pertumbuhan ekonomi suatu negara. Dengan demikian, pengawasan science and technology merupakan unsur terpenting usaha pencapaian tujuan pembangunan. Selain sebagai faktor penentu keberhasilan ekonomi, penggunaan teknologi yang dilakukan secara tidak bijaksana telah menimbulkan kerugian secara luar biasa baik bagi alam itu sendiri maupun bagi manusia.

Kondisi ini telah mendorong manusia untuk menemukan teknologi berwawasan lingkungan (environmentally sound technology), selain penggunaan cara-cara dan metode-metode pemanfaatan alam secara lebih bijaksana. ${ }^{2}$ Penggunaan teknologi yang berwawasan lingkungan merupakan unsur terpenting dalam memecahkan dikotomi antara usaha pemenuhan kebutuhan manusia terhadap pembangunan dan usaha perlindungan lingkungan yang selanjutnya menjadi komponen terpenting pembentukan strategi pembangunan berkelanjutan.

Konsep teknologi sangat luas, oleh karena itu terbuka dalam beberapa penafsiran, dari yang menitik beratkan pada aspek sosial, ekonomi, sampai pada yang memperhatikan aspek lingkungan. Salah satu konsep teknologi diajukan oleh The World Intellectual Property Organization (WIPO): ${ }^{3}$

"Technology means systematic knowledge for the manufacturer of a product, the application of process or rendering of a service, whether that knowledge be reflected in an invention, an industrial design, a utility model, or a new plant variety, or in technical information or skills, or in the service and assistance provided by experts for the design, installation, operation or maintenance of an industrial or commercial enterprice or its activities."

Definisi ini hanya menitik beratkan kepada peranan teknologi dalam kontek ekonomi atau industri, tetapi sama sekali tidak memperhatikan peranan teknologi untuk pemuasan "sosial-budaya" masyarakat penerima teknologi, dan juga tidak memperhatikan apakah kebutuhan ini merupakan kebutuhan negara pemberi teknologi atau penerima teknologi.

Dimensi sosial budaya dalam konsep teknologi dikemukakan oleh Organization for Economic Cooperation and Development (OECD) pada tahun 1981 menyatakan bahwa, teknologi meliputi: ${ }^{4}$

"The use of scientific knowledge by a given society at given moment to resolve concrete problems facing its development, drawing mainly at the means at its disposal,

${ }^{2}$ Deklarasi Stockholm 1972. Konsideran 1 dan 3.

3WIPO. 1987. Licensing Guide for Developing Countries. Genev: WIPO. HIm. 28

${ }^{4}$ Organization for Economic Cooperation and Development. 1981. North/South Technology Tranfer The Adjusment Ahead. Paris: Organization for Economic Cooperation and Development. HIm. 18. 
in accordance with its cultural and scale of values".

Pendekatan sosial budaya ini memberikan konsep teknologi yang dinamis dengan menghubungkan tahap pembangunan dalam kontek budaya masyarakat di mana teknologi itu diterapkan. ${ }^{5}$ Konsep teknologi ini juga menggambarkan ide "ketepatan atau kesesuaian" teknologi untuk dialihkän.

\section{Pengertian Alih Teknologi}

Ketergantungan négara berkembang terhadap teknologi dari negara maju merupakan suatu kenyataan yang tidak dápat diingkari. Negara berkembang sangat membutuhkan bantuan negara maju untuk mengadakan pengalihan teknologi. The United Nations Conference on Trade and Development (UNTAD) Draft Code of Conduct on Tranfer of Technology mendefinisikan alih teknologi sebagai: ${ }^{6}$

"Tranfer of systematic knowledge for the manufacturer of a product, for the application of process or of the rendering of a service and doesn't extend to the transaction involving a mere sale of goods".
Menurut definisi ini, alih teknologi merupakan pengalihan ilmu pengetahuan yang sistematis untuk pengolahan suatu produk, penerapan suatu proses atau pemberian bantuan teknis, namun tidak termasuk hanya semata-mata penjualan barang. Dari definisi tersebut peralihan teknologi itu hanya dalam lingkup nasional saja, sedangkan dari segi internasional alih teknologi terjadi melalui transaksi antara negara pemilik teknologi dan negara penerima teknologi. Menurut Blakeney segi internasional alih teknologi terjadi melalui transaksi antara negara pemilik teknologi dan negara penerima teknologi. Menurut Blakeney dimensi internasional alih teknologi dapat didefinisikan sebagai "The introduction into a country of technologies which exist elsewhere. but not yet in that country".

Pada saat ini tujuan negara berkembang sebagaimana tercermin dalam sebagian besar peraturan alih teknologi adalah bukan pemuasan, sementara kebutuhan sosial ekonomi melalui kesinambungan impor teknologi tetapi modifikasi atau kreativitas dari kemampuan teknologi mereka sendiri. ${ }^{8}$ Masalah alih teknologi berkaitan pula dengan pemilihan teknologi. Teknologi yang bagai-

5Lihat J.J. Murphy. " Retrospect and... " Dalam D.L.Specer dan A. Wowoniak. 1967. The Transfer of technology to Developing Countries. New York: Praegar. Him. 6. Dikatakan bahwa "Technology as a sociotechnological phenomena that is besides involving material and artifact improvements, technology is concidered to incorporate a cultural, social, and psychological process as well."

${ }^{6} \mathrm{D}$. Thomson. 1982. The UNTAD Code on Transfer of Technology. $1982 \mathrm{JWTL}$. HIm. 340.

${ }^{7} \mathrm{M}$. Blakeney. 1989. Legal Aspects of the Transfer of Technology to Development Countries. London Oxford: ESC Publishing. HIm. 135.

ELihat Economic and Social Council (ECOSOC). "Report on the Impact of Multinational Corporation on the Development Process and on International Relations." Document E/5500. Juni 1974. HIm.791 
manakah yang diperlukan untuk kemajuan pembangunan dan meningkatkan kesejahteraan rakyat. Kemudian, teknologi manakah yang diperlukan dan bagaimana cara memperolehnya dan mengembangkannya.

Adapun cara untuk memilih teknologi yang bermanfaat bagi suatu negara menurut United Nations Industrial Development Organization (UNIDO), antara lain: 9 Appropriateness of the national infrasrtucture for supporting the technologi; Value added and other contributions that the technology will make to the economy;Capability of the recipient of technologyto absorb and use it; Cost of the technology; Source of the technology and its supporting portfolio (patents, trade mark); Terms that will control the use of technology (i.e. , terms of the licensing agreement ).

\section{Aspek-aspek Hukum Alih Teknologi Aspek Hukum Internasional}

. Perkembangan perdagangan internasional, dan adanya gerakan perdagangan bebas mengakibatkan semakin banyaknya alih teknologi yang dilakukan antara negara maju dan negara berkembang. Oleh karena, alih teknologi berkaitan erat dengan hak milik intelektual khususnya hak milik perindustrian, maka makin terasa dibutuhkannya perlindungan terhadap hak milik intelektual yang sifatnya tidak lagi timbal balik, tetapi sudah bersifat antar negara.
Konvensi-konvensi internasional yang berkaitan dengan alih teknologi seperti Bern Convention, TRIPs, Patent Cooperation Treaty, dan Resolusi No. 32/186 tanggal 19 Desenber 1977 oleh Sidang Umum PBB yang membentuk International Code of conduct on the Transfer of Technology (ICCTT) yang disyahkan oleh Sidang Umum PBB tahun 1980. ICCTT dapat dikatakan sebagai suatu pengaturan alih teknologi yang terpadu, karena sebelumnya pengaturan tentang alih teknologi terpencar dalam berbagai perjanjian internasional maupun kontrak-kontrak internasional. Hanya saja karena ICCTT masih berupa Code, maka belum memiliki kekuatan hukum yang mengikat (non legally binding). Kemudian pada tanggal 22 Agustus 1988 UNCTAD telah mengesahkan "Set Principles and Rules for the Control of Restricted Business Practices ".10

Dalam praktek alih teknologi dilakukan melalui perjanjian internasional atau kontrak internasional.Perjanjian merupakan hukum bagi pihak-pihak yang mengadakan perjanjian. Hasil perjanjian diperoleh melalui suatu negosiasi, di mana masing-masing pihak mempunyai kekuatan. Oleh karenanya hukum perjanjian harus dipahami oleh para pihak yang mengadakan alih teknologi.

\section{Perjanjian Bilateral}

Perjanjian Bilateral dalam bidang alih teknologi pada umumnya berupa perjanjian

YUNIDO. "Development and Transfer of Technology Series No. 12." Guidelines for Evaluation of Transfer of Technology Agreement.

${ }^{10}$ Ari Purwadi. "Kebutuhan Akan Perangkat Hukum Perjanjian di Bidang Alih Teknologi.“"Majalah Hukum dan Pembangunan. FH Ul. 1993. HIm. 140. 
kerjasama teknis antara dua negara. Dalam perjanjian tersebut dirumuskan kesediaan atau kesanggupan salah satu pihak untuk membantu pihak lainnya dalam bidang yang menyangkut masalah teknis, ataupun kerjasama antar dua negara dalam bidang ilmu pengetahuan dan teknologi.

Perjanjian Bilateral ini pada hakikatnya telah mencerminkan kedudukan para pihak. Di mana satu pihak berperan sebagai pemilik atau pemberi teknologi dan dilain pihak sebagai penerima teknologi. Misal persetujuan antar Republik Indonesia dengan Perancis tentang kerjasama riset dan ilmiah pengembangan teknologi (Keppres No. 40 tahun 1979).

\section{Kontrak antara Perusahaan}

Pada umumnya alih teknologi ditempuh melalui jalur penanaman modal asing. Masalah penanaman modal asing diatur oleh negara yang bersangkutan, sehingga pengaturannya pun sepenuhnya diatur oleh hukum nasional masing-masing negara penerima modal asing tersebut. Akan tetapi, mengingat penanaman modalnya adalah perușaan transnasional, maka aspek internasional tidak dapat dilakukan begitu saja. Terkadang ada pula negara atau pemerintah yang langsung mengikatkan diri dalam kontrak atau perjanjian dengan perüsahaan transnasional dari negara lain.

Dalam perjanjian-perjanjian seperti ini, tentunya negara/pemerintah dapat turut serta mencampuri atau mengatur pelaksanaan kontrak, yang biasanya dalam bentuk memberikan arah, pedoman, petunjuk yang harus diikuti para pihak. Saluran lain yang juga sering ditempuh adalah kontrak lisensi, kontrak karya, kontrak kerjasama, dan lain-lain jenis kontrak anatarä perusahaan transnasional dengan perusahaan nasional.

Dalam kontrak-kontrak seperti ini yang. tampak lebih merupakan urusan dan kepentingan. pihak-pihak yang bersangkutan. Peranan negara dalam mencampuri dan mengaturnya tidaklah begitu besar. Kontrakkontrak tersebut di atas, merupakan hukum positif yang berlaku di dalam negara yang bersangkutan setidak-tidaknya bagi para pihak. Walaupun sifatnya internasional akan tetapi pelaksanaannya dilakukan dalam suatu wilayah negara, maka tentu akan menimbulkan implikasi hukum bagi negara yang bersangkutan.

\section{Aspek Hukum Nasional Alih Teknologi}

Selain diatur oleh peraturan internasional, alih teknologi juga diatur dalam hukum nasional suatu negara termasuk Indonesia. Semua peraturan yarig bermaksud mengatur proses pembangunan ekonomi nasional akan mempunyai pengaruh terhadap proses alih teknologi. Mulai dari penyusunan Garis Besar Haluan Negara dan pembangunan Lima Tahun sampai dengan peraturan perundangundangan tentang kehidupan ekonomi, seperti peraturan devisa, peraturan fiskal, peraturan perbankan dan pengaturan sekforsektor ekonomi, dan bidang-bidang industri tertentu. 11

"Sumantoro. 1989. Pengaturan Teknologi dalam Ruang Lingkup Pengaturan Hukum Ekonomi. Jakarta: UI Press. HIm. 48. 
Peraturan perundang-undangan yang mengatur alih teknologi, selain yang dicantumkan dalam Undang Undang No. 1 Tahun 1967 tentang Penanaman Modal Asing, secara tidak langsung dapat ditemukan dalam segala Undang-undang yang berkaitan dengan hak milik perindustrian, seperti Undang Undang. No. 14 Tahun 2001 Tẹntang Paten, Undang Undang No. 15 Tahun 2001 tentang Merek,Undang Undang No. 12 Tahun 1997 tentang Hak Cipta dan Undang Undang No. 5 Tahun 1984 tentang Perindustrian serta Undang Undang No. 11 Tahun 1967 tentang Ketentuan-ketentuan Pokok Pertambangan.

\section{Aspek-Aspek Hukum Alih Teknologi dalam Meningkatkan Daya Saing Produksi Teknologi Pertambangan di Indonesia Produksi Teknologi Pertambangan}

Kegiatan pertambangan 'sering menimbulkan kerusakan lingkungan yang cukup parah, oleh karena itu perlu diadakan peraturan yang bersifat komprehensif -untuk menangani masalah pertambangan, selain diperlukan juga teknologi pertambangan yang memenuhi standar internasional seperti ISO 9000 untuk standar mutu dan ISO 14000 untuk standar lingkungan. Kegiatan pertambangan di Indonesia diatur dalam Undang-undang No. 11 tahun 1967 tentang Ketentuan-ketentuan Pokok Pertambangan.

Teknologi pertambangan merupakan suatu unsur yang penting dalam meningkatkan produksi pertambangan di Indonesia, mengingat Indonesia merupakan suatu negara yang cukup banyak memiliki kekayaan alam yang berujud tambang. Berbagai macam tambang yang berada di wilayah Indonesia membutuhkan suatu penanganan yang serius untuk dapat dimanfaatkan seçara optimal demi kemakmuran rakyat. Kalau dalam kenyataannya, Indonesia ternyata belum mampu untuk mengoptimalkan pemanfaatan tambang yang dimilikinya, salah satu penyebabnya adalah masih kurangnya teknologi pertambangan -yang dimilikinya dan juga karena peraturan-peraturan perundangundangan yang ada belum menunjang pengembangan teknologi pertambangan $\mathrm{di}$ Indonesia.

Dengan masuknya Indonesia-sebagai anggota WTO, hal ini membawa konsekuensi bahwa Indonesia harus mentaati aturan main yang ada di WTO.. ${ }^{12}$ Dengan adanya liberalisasi perdagangan ini,mengakibatkan setiap negara untuk berjuang memperoleh pangsa pasar di masyarakat internasional, maka indonesia harus memiliki keunggulan komparatif maupun keunggulan kompetitif dalam perdagangan baik di bidang barang maupun di bidang jasa.

Pèmbentukan dan pengembangan aturan hukum di bidang teknologi pertambangan sangat diperlukan, karena adanya suatu kepastian hukum dan peraturan yang memberikan kemudahan masuknya modal asing akan dapat menarik masuknya investasi ke Indonesia. Investasi ini sangat dibutuhkan oleh Indonesia untuk pertumbuhan ekonomi pada khususnya dan mencapai tujuan pembangunan pada umumnya, apalagi untuk keadaan Indonesia yang sekarang ini sedang

${ }^{12}$ H.S. Kartadjoemena. 1997. GATT WTO dan Hasil Uruguay Round. Jakarta: UI-PRESS. HIm.14-15. 
Sri Wartini. Aspek-aspek Hukum Alih Teknologi dalam Meningkatkan...

mengalami krișis di berbagai bidang yang tak kunjung selesai.

\section{Bentuk-bentuk Perjanjian Alih Teknologi Pertambangan}

Perjanjian alih teknologi di bidang pertambangan khususnya mengenai teknologi pertambangan dapat dilakukan dengan cara yang bermacam-macam, namun dalam di sini hanya akan dibatasi pada perjanjian-perjanjian internasional yang memberikan manfaat yang cukup besar dalam meningkatkan daya saing produksi teknologi pertambangan di Indonesia. Perjanjian Lisensi Paten merupakan salah satu cara pengalihan teknologi pertambangan

\section{Perjanjian Lisensi Paten}

Perjanjian lisensi pada umumnya merupakan persetujuan kontraktual yang menyangkut penggunaan berbagai macam hak milik perindustrian (industrial property rights) untuk dimanfaatkan lebih lanjut di dalam kegiatan-kegiatan industri pada swasta nasional di negara-negara yang menerima penyerahan hak-hak milik industri tersebut. Perjanjian lisensi sering digunakan untuk produksi teknologi pertambangan di Indonesia. Perjanjian lisensi yang lazim dikenal dalam berbagai kerjasama investasi, yakni perjanjian-perjanjian lisensi paten dan merek dagang. Perjanjian lisensi merek dagang dan lisensi paten umumnya dilakukan secara bersama-sama, namun tidak jarang mengingat pertimbangan-pertimbangan khusus, kedua bentuk perjanjian di atas dapat pula saling terpisah.

Dalam rangka meningkatkan daya saing di bidang teknologi pertambangan, maka harus dipilih suatu teknologi yang ramah lingkungan, mengingat exploitasi yang dilaksanakan dalam bidang pertambangan membawa dampak yang cukup besar terhadap lingkungan baik itu lingkungan sosial maupun lingkungan biologi. Apalagi sekarang ini isu lingkungan merupakan isu yang sudah dimasukkan dalam perdagangan internasional, sehingga produk-produk yang tidak ramah lingkungan tidak akan dapat memasuki pangsa pasar yang mensyaratkan lingkungan sebagai salah satu komponennya. Oleh karena itu, persyaratan bahwa suatu teknologi tertentu, dalam hal ini teknologi pertambangan harus memasukkan persyaratan lingkungan di dalam kontrak perjanjiannya. Sehingga suatu kontrak lisensi harus memuat suatu jaminan bahwa teknologi tersebut ramah lingkungan; selain perrsyaratan-persyaratan lain seperti harga yang tidak terlalu tinggi, persyaratan bahwa tenaga kerja indonesia akan memperoleh keahlian dari teknologi tersebut yang dapat dilakukan melalui pelatihan baik di dalam maupun di luar negeri.

Namun demikian, mitra usaha asing dalam lisensi paten dan merek dagang ini, telah mempunyai suatu pola standar yang dapat diterapkan di berbagai negara penerima teknologi. Hal-hal khusus yang masih perlu dirundingkan terutama menyangkut jumlah dan cara pembayaran royalti yang merupakan hak bagi pihak asing, dan data teknik serta hal-hal lain perlu disediakan sebagai hak bagi pihak lokal. Setiap hak yang dimiliki pihak asing akan menjadi kewajiban bagi pihak lokal, dan begitu pula sebaliknya. Sehingga kalau dalam suatu kontrak yang. sudah standar ini belum dimasukkan unsur lingkungan; maka perlu untuk dimasukkan. Akan tetapi ini tentu saja akan menyulitkan bagi pihak pemberi 
lisensi karena berarti teknologinya memang merupakan teknologi yang ramah lingkungan. Dalam hal ini berarti membutuhkan suatu kejelian untuk memilih teknologi yang ramah lingkungan. Selain itu bahwa teknologi pertambangan tersebut juga harus memenuhi standar mutu yaitu ISO 9000 atau jika memungkinkan bahwa produk teknologi tersebut harus memiliki standar lingkungan yaitu memiliki sertifikat ISO 14000: $:^{13}$

Pemberian -lisensi secara eksklusif dimaksudkan agar pihak pemberi lisensi dapat dengan lisensinya memasarkan produkproduk di bawah lisensi negara penerima lisensi merupakan daerah pemasaran yang potensial bagi pemasaran barang-barang produksi yang dipateñkan atau know-how. Sebaliknya, pemberian hak menggunakan paten/know-how secara non eksklusif dimaksudkan agar pihak lisensi dapat menggunakan paten/know-how di daerah/ negara ketiga.

\section{Perjanjian know-how}

Bagi negara berkembang, pemilihan cara alih teknologi dari negara maju harus mempertimbangkan banyak faktor, antara lain ialah mengenai harga teknologi itu sendiri, serta cara pengalihan yang paling bermanfaat bagi negara tersebut. Know-how terletak antara bantuan teknik dan paten. Bantuan teknik, know-how merupakan suatu paket informasi, namun tidak sama dengan bantuan teknik karena beberapa informasi dari know-how ada yang bersifat rahasia.Tidak seperti paten, know- how tidak memiliki perlindungan hukum seperti paten, pihak ketiga berhak untuk mempergunakan maupun menggunakan know-how yang tidak dipatenkan.

Perlu ditegaskan bahwa "know-how" biasanya berfungsi untuk menunjang paten, karena di dalamnya terdapat pengetahuan, ketrampilan dan berbagai pengalaman serta rahasia yang menghasilkan barang-barang yang dipatenkan dan kemudian dipasarkan secara komersial. Hal ini berarti bahwa pemberian lisensi paten saja ternyata tidak cukup tanpa disertai dengan kewajiban dari pemilik paten untuk memberikan data-data dan informasi teknik bagi penggunaan hak paten dalam rangka menghasilkan produk yang diharapkan dan siap dipasarkan. Apalagi untuk alih teknologi produkși teknologi pertambangan yang begitu rumit, tentu akan membutuhkan know-how selain lisensi paten. Oleh karena itu, perjanjian lisensi paten perlu memuat pula ketentuan mengenai penyediaan data-data dan informasi teknik

\section{Perjanjian Bantuan Teknik}

Bantuan teknik termasuk klasifikasi yang tidak dipatenkan, dia berada antara paten dan know-how. Pengertian technical assistance dan technical services hanya meliputi komponen-komponen teknis dan jasa-jasa berada di luar know-how dan paten. Berkaitan dengan itu, perlu dikemukakan bahwa informasi dan keterampilan teknik dapat dikembangkan pihak penerima lisensi melalui kegiatan riset dan pengembangan atau penerapan teknik-teknik industri dan perdagangan dalam. mengadakan

${ }^{13}$ Brian Rothery. 1996. Sistem Manajemen Lingkungan ISO 14000. Jakarta: Pustaka Binaman Pressindo. HIm. 5. 
perusahaan patungan. ${ }^{14}$ Perjanjian bantuan teknik dapat dimuat dalam perjanjian lisensi paten atau know-how atau pelengkap bagi. pemakaian kedua hak milik perindustrian tadi. Karena itu, jasa pemberian bantuan teknikdalam perjanjian lisensi dirumuskan dalam. klausul technical assistence and other information and skill"

Kerjasama bantuan teknik mengatur tentang penyediaan know-how, instruksioperasional dan pemberian latihan bagi pekerja dari penerima lisensi oleh pemberi lisensi. ${ }^{15}$ Selain itu, perjanjian bantuan teknik juga memuat mengenai cara perawatan mesin dan peralatan tersebut berdasarkan instruksi operasional serta pemberian training bagi tenaga kerja.

Nilai lebih dari bantuan teknik terletak pada pengalaman pemberi bantuan teknik dalam suatu produk tertentu secara komprehensip, profesional, kompetitif dan merupakan satusatunya sumber bantuan yang dapat menyebabkan si penerima bantuan teknis mampu untuk memfasilitasi produksi secara cepat dan ekonomis untuk memperoleh pasar secara efektif.

Dalam perjanjian bantuan teknis si penerima bantuan teknis membayar atas informasi dan jasa-jasa yang sudah terdaftar dalam perjanjia tersebut. Perjnjian ini sangat diperlukan dalam pengembangan dan peningkatan daya saing produksi teknologi pertambangan jika dirumuskan dalam suatu perjanjian yang fair. ${ }^{16}$

\section{Kontrak Menejemen (Manageiment Contract)}

Kontrak manajemen merupakan perjanjian yang berkaitan dengan suatu-usaha, misalnya, dalam hal ini adalah pertambangan. Pihak pemilik modal yang berusaha di bidang pertambangan disebut sebagai owner, sedangkan pihak yang memiliki kemampuan manajerial disebut operator.

Dalam usaha pertambangan, fungsi manajerial yang dilakukan oleh pihak operator dapat meliputi manajemen produksi, manajemen tenaga kerja, termasuk perekrụtan dan pengarahan tenaga kerja asing dan tenaga kerja lokal, pembelian dan. usaha mendapatkan barang modal dan bahan mentah, pemasaran, manajemen keuangan, termasuk perjanjian mengenai pendanaan pinjaman.

\section{Jenis Teknologi yang Berwawasan Lingkungan Sebagai Pendukung Daya Saing Produksi Teknologi Pertambangan di Indonesia}

Alih teknologi yang berwawasan lingkungan. merupakan suatu keunggulan tersendiri, selain untuk mendukung pembangunan yang berkelanjutan juga untuk

${ }^{14}$ WIPO. "Licensing Patent Methods and Arrangement for the Commercial Transfer and Acquisition of Technology" Bureau of WIPO 1990. HIm. 5.

${ }^{15}$ Michel A. Lichter. Op.Cit. HIm. 7.

${ }^{16}$ Seringkali negara penerima teknologi, karena memiliki posisi yang lemah, dan juga kurangnya informasi tentang teknologi yang bersangkutan tidak dapat melakukan negosiasi secara seimbang. 
merebut pangsa pasar di negara yang memiliki standar lingkungan yang tinggi. Sehingga dalam peraturan alih teknologi misalnya dalam kontrak-kontrak disyaratkan bahwa teknologinya ramah lingkungan. Dalam perjanjian alih teknologi pertambangan, persyaratan tersebut sangat diperlukan karena memang sudah terbukti bahwa penggunaan teknologi pertambangan yang tidak ramah lingkungan. menimbulkan permasalahan lingkungan yang cukup serius. Misalnya usaha pertambangan yang dilakukan oleh PT. Free Port di Irian Jaya. ${ }^{17}$

Mengapa negara-negara berkembang seperti Indonesia membutuhkan teknologi yang berwawasan lingkungan? $\mathrm{Hal}$ ini disebabkan beberapa pertimbangan, antara lain; Pertama adalah alasan perlindungan lingkungan. Teknologi pertambangn yang berwawasan lingkungan adalah teknologi yang sedikit limbah. Dalam teknologi jenis ini sudah sejak awal pencegahan limbah yang potensial pun sudah diantisipasi. Kedua, alih teknologi yang berwawasan lingkungan, merupakan keseluruhan sistem yang meliputi know-how, prosedur, material, jasa, dan peralatan-peralatan sebagaimana juga prosedur organisasi dan cara mengelolanya. ${ }^{18}$

Sangatlah diperlukan suatu pengaturan yang terpadu antara peraturan alih teknologi dan juga peraturan perlindungan lingkungan, jadi dalam hal ini peranan pemerintah sebagai lembaga yang berhak memberikan ijin untuk beroperasinya suatu usaha di bidang pertambangan sangatlah penting. Sehingga perlu diadàkan suatu pendekatan yang terpadu dari berbagai pihak, baik itu dari pihak swasta maupun pemerintah sebagai penentu kebijaksanaan dalam alih teknologi dan seharusnya juga berfungsi sebagai pengawas mengenai macam teknologi apa saja yang dibutuhkan oleh masyarakat Indonesia dalam rangka untuk meningkatkan daya saing produksi teknologi pertambangan.

\section{Peranan Peraturan}

\section{Perundang-undangan dalam} Meningkatkan Daya Saing Produksi Teknologi Pertambangan di Indonesia

Peraturan perundang-undangan merupakan salah satu faktor penting dalam menarik masuknya investor asing ke suatu negara. Penanaman modal di bidang pertambangan sangat dibutuhkan dalam rangka untuk meningkatkan daya saing produksi teknologi pertambangan, karena produksi ini membutuhkan modal yang cukup besar jika ingin bersaing di pasar Internasional maupun untuk pangsa pasar di dalam negeri.

Peraturan perundang-undangan di bidang alih teknologi sangatlah dibutuhkan, karena hal ini akan dapat dipergunakan untuk mencegah masuknya teknologi-teknologi yang tidak ramah lingkungan ke Indonesia. Akan tetapi, kalau peraturannya saja tidak ada, maka

${ }^{17}$ Proyek pertambangan tembaga yang dilakukan oleh PT Free Port ini telah menimbulkan pencemaran lingkungan yang cukup parah, sehingga menimbulkan protes dari masyarakat, bahkan masyarakat menuntut supaya usaha pertambangan tersebut ditutup.

1eUNCED. " Environmentally Sound Technology: Chapter 34 of Agenda 21. " 22/4 EPL. 1992. Him. 94. 
akan bebas teknologi itu masuk ke Indonesia tanpa ada yang dapat mencegahnya. Peraturan perundang-undangan yang secara tidak langsung berkaitan dengan alih teknologi, antara lain ialah perundangundangan di bidang HAKI (Hak Atas Kekayaan Intelektual), hal itu sebagai konsekuensi keikutsertaan Indonesia dalam World Trade Organization (WTO). ${ }^{19}$ Tindakan yang dilakukan oleh pemerintah Indonesia untuk memberikan perlindungan standar di bidang HAKI yaitu dengan jalan merevisi undangundang di bidang HAKI melalui Undang No. .Tahun 2001 Tentang Hak Cipta yang ketika tulisan ini dibuat belum selesai.

Kaitannya dengan peningkatan daya saing produksi pertambangan ialah dengan adanya peraturan perundang-undangan tersebut akan memberikan perlindungan hukum bagi penemu teknologi baru di bidang pertambangan, baik itu dilakukan melalui modifikasi lisenși paten teknologi pertambangan maupun melalui penelitian dan pengembangan (research and development). Dengan adanya perlindungan hukum yang pasti ini akan mendorong perkembangan di bidang penemuan teknologi baru, selain juga dibutuhkan iklim yang kondusif untuk penemuan teknologi baru di bidang produksi teknologi pertambangan.

Perundang-undangan di bidang HAKI perlu memperoleh dukungan dari perundangundangan lain, jika menghendaki teknologi ini tidak merusak lingkungan. Dalam rangka pelaksanaan alih teknologi dalam bidang teknologi pertambangan yang berwawasan lingkungan harus dikaitkan juga dengan Undang Undang No. 23 Tahun 1997 tentang Pengelolaan llngkungan Hidup dan Juga Peraturan Pemerintah tentang Baku Mutu, maupun ketentuan tentang AMDAL. Hal tersebut sangat penting dilakukan untuk mencegah masuknya teknólogi pertambangan yang tidak berwawasan lingkungan.

Selain memperhatikan berlakunya Undang-undang tersebut di atas, maka sudah tiba masanya indonesia mempunyai Undangundang alih teknologi tersendiri yang merupakan transformasi dari International Code of Conduct on The Transfer of Technology ( ICCTT ) yang berfungsi sebagai pedoman dasar dalam alih teknologi internasional. Undang-undang alih teknologi tersebut hendaknya dapat pula berfungsi sebagai alat pemersatu dan koordinator terhadap perundang-undangan yang mempunyai aspek hukum alih teknologinya. Hal ini perlu guna menjamin keselarasan dalam pelaksanaan, sehingga tercapai apa yang menjadi tujuan alih teknologi tersebut.

\section{Simpulan}

Aspek-aspek hukum yang dapat meningkatkan daya saing produksi teknologi pertambangan di Indonesia ialah aspek hukum internasional yang berupa perjanjianperjanjian internasional maupun Code of Conduct, sedangkan Aspek Hukum Nasional

${ }^{19}$ Achmad M. Ramli. 2000. H.A.K.I, Teori Dasar Perlindungan Rahasia Dagang. Bandung: Mandar Majü. HIm. 6. 
Berupa peraturan perundang-undangan di Bidang H.A.K.I, baku mutu, lingkungan maupun peraturan-peraturan terkait lainnya.

Untuk dapat mencapai tujuan alih teknologi sebagaimana yang tercantum dalam kebijakan nasional, maka perlu diadakan suatu pengawasan terhadap jenis teknologi yang masuk ke Indonesia. Perjanjian-perjanjian alih teknologi yang dilakukan baik oleh pihak pemerintah maupun swasta nasional harus dibuat secara terperinci mengenai hak dan kewajiban para pihak secara adil dan rasional, sehingga tidak terjadi perjanjian yang tidak fair.

Sangat diperlukan adanya Undangundang yang khusus mengatur alih teknologi yang didasarkan kepada konvensi-konvensi internasional yang berkaitan dengan alih teknologi maupun International Code of Conduct on the Transfer of Technology (ICCTT), sehingga terjadi harmonisasi antara peraturan nasional dan internasional. Selain itu perlu peningkatan keahlian di dalam pembuatan kontrak-kontrak internasional sehingga dapat dihindari pencantuman klausul-klausul yang merugikan pihak Indonesia.

Peningkatan keahlian dan ketrampilan tenaga ahli Indonesia dalam bidang teknologi pertambangan yang sesuai dengan kebijakan nasional sangatlah signifikan untuk ditingkatkan baik melalui pelatihan maupun pendidikan secara formal yang dilakukan di dalam maupun di luar negeri. Sehingga dapat meńingkatkan bargaining power yang selama ini lemah, yang antara lain disebabkan kurangnya pengetahuan maupun keahlian yang dimiliki oleh personil-personil yang melakukan perjanjian alih teknologi. Selain itu juga sangatlah penting untuk memperoleh akses informasi perkembangan teknologi dalam masyarakat internasional, untuk mengantisipasi supaya teknologi yang dialihkan sebetulnya sudah menjadi public domain bahkan sudah tidak dipakai lagi di negeri asalnya.

\section{Daftar Pustaka}

Achmad M. Ramli. 2000. H.A.K..I, Teori Dasar Perlindungan Rahasia Dagang. Bandung: Mandar Maju.

Blakeney, M.. 1989. Legal Aspects of the Transfer of Technology to Development Countries. London Oxford: ESC Publishing.

Economic and Social Council (ECOSOC). "Report on the Impact of Multinational Corporation on the Development Process and on international Relations." Document E/5500. Juni 1974.

Kartadjoemena, H.S.. 1997. GATT WTO dan Hasil Uruguay Round. Jakarta: UIPRESS.

Mazrui, A.A. . "Exit from the World System: Dilemmas of Cultural and Economic Disengagement. "Dalam A. Gauhar. 1983.Third World Startegy Economic and Politic Cohesion in the South. New York: Praegar.

Murphy, J.J.. "Retrospect and... "Dalam D.L.Specer dan A. Wowoniak. 1967. The Transfer of technology to Developing Countries. New York: - Praegar.

Organization for Economic Cooperation and Development. 1981. North/ South Technology Tranfer The Adjusment 
Ahead. Paris: Organization for Economic Cooperation and Development.

Purwadi, Ari. “ Kebutuhan Akan Perangkat Hukum Perjanjian di Bidang Alih Teknologi." Majalah Hukum dan Pembangunan. FH Ul. 1993.

Rothery, Brian. 1996. Sistem Manajemen Lingkungan ISO 14000. Jakarta: Pustaka Binaman Pressindo.

Sumantoro. 1989. Pengaturan Teknologi dalam Ruang Lingkup Pengaturan Hukum Ekonomi. Jakarta: UI Press.

Thomson, D. 1982. The UNTAD Code on Transfer of Technology. 1982 JWTL.
UNCED. “ Environmentally Sound Technology: Chapter 34 of Agenda 21. " 22/4 EPL. 1992.

UNIDO. "Development and Transfer of Technology Series No. 12." Guidelines for Evaluation of Transfer of Technology Agreement.

WIPO. 1987. Licensing Guide for Developing Countries. Genev: WIPO.

"Licensing Patent Methods and Arrangement for the Commercial Transfer and Acquisition of Technology" Bu-. reau of WIPO 1990. 